\title{
大規模地震時における帰宅困難者支援に関する一考察*
}

\section{Supporting Measures for the Difficult to Return Home at the Earthquake Disaster *}

永田 尚人 ${ }^{* *}$ 西村 典子 ${ }^{* *} \cdot$ 山本 幸司 ${ }^{* * *}$

By Hisato NAGATA $^{* *} \cdot$ Noriko NISHIMURA $^{* * *} \cdot$ Koshi YAMAMOTO $^{* * *}$

\section{1.はじめに}

阪神・淡路大震災は，大都市を襲った直下型の地震で あったため，神戸を中心とする阪神間の諸都市は壊滅的 な打撃を被り，多大な人的・物的被害を受けた. ライフ ラインである水道・電気・ガス・電話等は寸断され，都 市生活は麻痺し，それに加えて，鉄道，道路，港湾，河 川等の都市インフラにも甚大な被害が発生した. 幸いに も, 休日明けの午前5時46分という社会経済活動が開始 する前の時間带であったため, 通勤・通学者は交通輸送 機関による直接的な被災を免れた。

阪神・淡路大震災における神戸市など，昼間時の大都 市中心部には多数の通勤・通学，買い物等を目的とする 滞在者が存在する. 平成 9 年度に公表された東京直下地 震の被害想定 ${ }^{11}$ にると，滞在者数は東京都全体で 1 日 平均約 819 万人，区部において約 695 万人にのぼると想 定されている. このため, 大規模地震発災直後において, 主要な輸送機関である鉄道の運行停止や不通区閒の発生 により，多くの帰宅困難者の発生が予測されている.

これらの帰宅困難者は徒歩により帰宅を行うものと考 えられるが，帰宅経路の安全状態や被害状況に関する情 報とともに，長時間にわたる帰宅行動における食料や飲 料水の確保が大きな課題となる.

そこで本研究では, 発災後における交通輸送機関の麻 盘により発生する帰宅困難者の問題点を明らかにした上 で飲食料等確保のあり方の示唆を目的とする.

\section{2. 帰宅困難者対策における問題点}

東京都では帰宅困難者を，「震災時に交通機関が使用 できなくなったとき，自宅が遠距離のため徒歩による帰

* キーワーズ : 防災計画 (帰宅困難者、緊急物資)

**正員、工修、（株）熊谷組プロジェクトエンジニアリング室 (東京都新宿区津久戸町 2-1、TEL03-5261-5526、 hnagata@ku.kumagaigumi.co.jp)

*学生員、名古屋工業大学大学院社会工学専攻博士前期課

程、（名古屋市昭和区御器所町、TEL052-735-5425)

*相正員、工博、名古屋工業大学大学院社会工学尃攻 (名古屋市昭和区御器所町、TEL052-735-5425)
宅が困難となる外出者」と定義している. 東京直下地震 の被害想定では，こうした帰宅困難者が約371万人発生 すると予想されており，大きな社会的混乱か懸念されて いる1).

中央防災会議 2 ，東京都 ${ }^{3)}$ 等の資料によると，帰宅困 難者対策として，(1)普及啓発，(2)情報収集・提供，(3)事 業所・学校・施設における対策, (4)ターミナル駅周辺の 対策，(5)徒歩帰宅支援，66代替輸送，の各項目について 対応策を検討しているが，具体的な対応を取るためには 克服すべき課題が表一 1 に示すように山積している。

大量の帰宅困難者を円滑に帰宅させるためには，一次 的な休息場所などの帰宅支援施設の配置や支援体制の構 築が必要になる. 発災時間帯が夜間や早朝となった場合 には，一時避難場所および長距離の帰宅経路上での飲食

\section{表-1 帰宅困難者対策とその問題点（課題）}

\begin{tabular}{|c|c|}
\hline 対策項目 & 問題点・課題 \\
\hline 普及啓発 & $\begin{array}{l}\text { ・帰宅困難の状況が具体的に理解できない } \\
\text { •事業所等が帰宅困難問題への意識が低いと } \\
\text { ともに何をやって良いのか分らない }\end{array}$ \\
\hline $\begin{array}{l}\text { 情報収集‧ } \\
\text { 提供 }\end{array}$ & $\begin{array}{l}\text { ・国, 自治体等の関係機関が帰宅困難問題の } \\
\text { 情報を共有する体制になっていない } \\
\text { ・各情報提供手段の災害時の信頼性について } \\
\text { 検討が必要である } \\
\text { ・帰宅経路の被害状況の情報が必要 }\end{array}$ \\
\hline $\begin{array}{l}\text { 事業所・学 } \\
\text { 校・施設に } \\
\text { おける対策 }\end{array}$ & $\begin{array}{l}\text { •事業所, 不特定多数収容施設が, 帰宅困難 } \\
\text { 者対策の主導をとらなければならないこと } \\
\text { 〜の認識不足 } \\
\text { ・ 中小規模の施設での取組みができない }\end{array}$ \\
\hline $\begin{array}{l}\text { ターミナル } \\
\text { 駅対策 }\end{array}$ & $\begin{array}{l}\text { ・駅と地元の連絡体制の不備 } \\
\text { •鉄道は本社が対策の方針全てを決めるため } \\
\text { 駅独自の対応ができない }\end{array}$ \\
\hline $\begin{array}{l}\text { 徒歩帰宅支 } \\
\text { 援 }\end{array}$ & $\begin{array}{l}\text { •徒歩帰宅支援機関間の役割分担，調整が取 } \\
\text { られていない } \\
\text { ・水，食料の備蓄は行政区域内の住民への対 } \\
\text { 策であり帰宅困難者向けではない } \\
\end{array}$ \\
\hline 代替輸送 & $\begin{array}{l}\text { ・発災時においては救出活動等の緊急輸送が } \\
\text { 主体であり帰宅困難者輸送は困難 } \\
\text { ・移送実施僟関の広域的な対応が必要. しか } \\
\text { し，役割分担等の調整の検討が不十分 }\end{array}$ \\
\hline
\end{tabular}


料の確保が重要な課題となっている.これらの備蓄は通 勤・通学者の所属組織で対応することが原則となってい るが，買物客を含めてその対応力は脆弱であり，社会的 なシステムを構筑することは非常に有益な事項と考えら れる. 本稿では, 東海地震を対象にし, 徒歩帰宅者の支 援に関する問題提起を行うとともに，情報提供を含めた 支援施設として，コンビニエンスストア（以下，コンビ ニとする）の可能性について検証を行う.

\section{3. 徒歩帰宅者の支援に関する問題提起}

大量の帰宅困難者を円滑に帰宅させるためには，一次 的な休息場所などの帰宅支援施設の配置や，帰宅経路上 での飲食料確保などの支援体制構築が必要になる．特に， 発災が冬季や夏季の自然条件の厳しい時期となる場合に は，長時間にわたる徒歩帰宅は体力の消耗が激しいなど, 経路上での休㮩施設の設置が重要な検討課題となる.

平成10年に行われた東京都庁防災訓練において実施さ れたアンケート結果では，水，食料，トイレ，休息所に

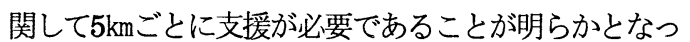
ている4).これに対し，名古屋市では「名古屋市地域防 災計画」で「公共交通機関の運行停止等により通常の帰 宅等が困難となった滞留者に対し，原則として徒歩によ る帰宅を促す」こと，徒歩帰宅者支援に関しては，「市 の施設, 避難場所 (小中学校のグラウンド) において可 能な範囲で䚻宅支援を実施する」ことを記述し，具体的 には「飲料水の提供，トイレの提供，休息場所の提供， 帰宅支援情報の提供等とする」としている5)。しかしな がら，具体的な施設数，施設規模，配置密度等の詳細計 画は立案されていない．また，避難所となる市立小中学 校には多くの地域住民が避難している可能性が高く，徒 歩帰宅者が支援を求めて殺到すれば大混乱が想定される。

本稿では，このように大きな社会的混乱が懸念される 帰宅困難者問題に関して, 表一 1 に示す対策のうち自助 では対応が困難と考えられる課題に対して，発災時の混 乱から一時的に避難させるため実効性のある具体的な計 画策定の核となると思われる以下の問題を提起し，コン ビニを活用した対策について検討を行う.

(1) ターミナル駅における滞留者に関する問題提起

$\mathrm{J} R$ 等の各交通事業主体には，滞留者が駅周辺への避 難や徒歩による帰宅行動を早期に意思決定するための情 報伝達, 避難所一の誘導等適切な措置が求められる.

(2) 徒步帰宅者への支援に関する問題提起

地域住民を対象とした一般的な避難所においては徒歩 帰宅者への支援は困難であり，一時的な徒涉帚宅者向け の休息施設等の設置が必要とされる.

(3) 帰宅困難者の保護に関する問題提起

名古屋市が民間事業者との間で締結した帰宅困難者支
援用の施設には飲食料備蓄がないため，緊急物資を短時 間に調達するシステムの構築が必要とされる.

\section{4. 阪神・淡路大震災におけるコンビニの対応 ${ }^{6)}$}

（1）震災後の店舗の営業状況

神戸市をはじめとする各自治体は，被災者への飲食料 等の生活必需品の提供に向けて，全国各地加救援物資 を受入れ，各避難所一供給する救援物資供給システムを 立ち上げた. しかしながら，行政も想定していなかった 大災害のため，このシステムが完全に機能し，被災者に 過不足なく，円滑に輸送できるまでには多大な時間を要 した. そこで行政および被災者はコンビニをはじめとす る小売店にも物資供給を求めた. コンビニではこれを受 けて, 震災後も可能であれば原則として営業を行い，被 災者に物資を供給するべく早期に営業を再開した. 店頭 には入場制限を行わなければならないほどの長蛇の列が でき，被災者の物資調達の観点および民間からの物資供 給の観点からコンビニの営業は非常に有用であった.

図一1は, 被害の大きかった神戸市内における某大 手コンビニチェーンの開業店舗数の推移を示している. これによると, 震災の翌1月18日から少しずつ営業を再 開し始め, 22日には半数以上の店舗が営業を再開して いる. しかし，1月21日に開業店舗数が一時減少してい るのは，交通被害等の諸事情により納品車が到着せず， 商品が不足したためと思われる.このような観点から判 断すると，現状でのコンビニに発災直後（当日，翌日） の帰宅困難者への飲食料の提供機能を求めることは困難 である.

（2）震災後の障害とその対策

表一 2 は, 震災直後に営業を一時停止していた店舗が 営業を再開する際に障害となった主な要因と, コンビニ チェーンが行った対策をまとめたものである.これらの 対策により, 図一 1 で示したように発災後数日の閒にコ ンビニチェーンは営業再開店舗数の拡大を可能とした. 早期営業再開の外的要因として二つの事項があげられる.

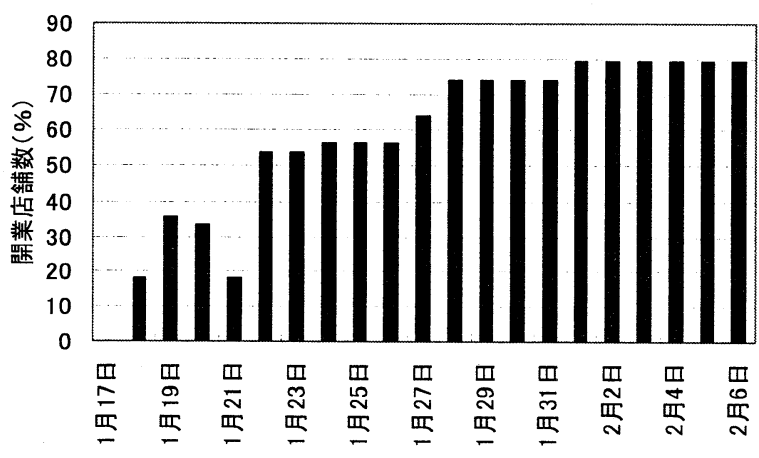

図一1 某大手コンビニチェーンにおける開業店舗数の推移 
表ー2 コンビ二営業における障害とその対策

\begin{tabular}{|c|c|}
\hline 障 害 & 対 \\
\hline 通信手段 (電話) & - 徒歩等で店舗状況を確認 \\
\hline 等)不通によりコ & ・POS システムが使用不可能なため, \\
\hline ンビニ各店舗と & 配送方法は商品を限定し，1日3回 \\
\hline の交信が困難 & の配送のみとした \\
\hline 神戸市内の配送 & - 使用可能な近隣配送ゼターに一本化 \\
\hline センターの被災 & ・早期に神戸配送センターを修復 \\
\hline 従業員の確保が & ・被災地外から多くの営業担当を派遣 \\
\hline 困難 & \\
\hline
\end{tabular}

一つは，コンビニの営業に必須である電力が比較的早 く復旧したことであり，もう一つは，被災地域内の大混 乱にもかかわらず配送車に「緊急物資輸送」と表示すれ ば被災地域の警察・消防は通行を妨げなかったため，緊 急物資発送地の警察等で緊急車両指定を申請すると支援 物資輸送として許可証を発行してもらえたことである.

（3）大規模地震災害時における課題

以上のように，コンビニは被災者にとって非常に有用 であったといえるが，同時に今後への課題も明らかにな った. コンビニ特有の配送方法である「ジャスト・イン・ タイム」が災いし, 納品車が店舗に到着しなければ商品 はすぐに品切れとなり, 電力がストップするとPOSレジ スターが使用不可となり営業が困難となった．また，発 災直後ではアルバイト従業員の確保も险路となった。

\section{5. 東海地震における帰宅困難者対策}

\section{（1）東海地震における帰宅困難者数}

愛知県防災会議による東海地震等の被害予測調査報告 書によると，帰宅困難者数は表一3に示すように推定さ れている7). 突発地震時においては, 名古屋市で半数近 い47万人をはじめとして, 岡崎市, 豊田市を中心に愛知 県内で約 100 万人に近い帰宅困難者が発生すると予測さ れている. 表中の数值は, 各市町村で発生する㷌宅困難 者を示しており, 愛知県の数值は各市町村の合算值であ る. 例えば，名古屋市の数值は昼間に名古屋市に滞在し ている人のうち帰宅困難になる人数を示している. 東海地震では, 警戒宣言発令の有無により震災前後の状 沉が大きく異なると予想され，震災前に判定会が召集さ れれば，公共交通機関の利用がまだ可能であるこの段階

\section{表一3 愛知県おける東海地震の帰宅困難者予測}

\begin{tabular}{|c|c|c|c|c|c|c|}
\hline & \multicolumn{3}{|c|}{ 突発地震時 (人) } & \multicolumn{3}{|c|}{ 警戒宣言時 (人) } \\
\cline { 2 - 7 } & $\begin{array}{c}\text { 就業者· } \\
\text { 就学者 }\end{array}$ & 私事等 & 計 & $\begin{array}{c}\text { 就業者· } \\
\text { 就学者 }\end{array}$ & 私事等 & 計 \\
\hline 名古屋市 & 331,549 & 138,688 & 470,237 & 192,188 & 48,545 & 240,733 \\
\hline $\begin{array}{c}\text { 愛知県 } \\
\text { 全体 }\end{array}$ & 651,822 & 323,381 & 975,203 & 282,579 & 77,007 & 359,586 \\
\hline
\end{tabular}

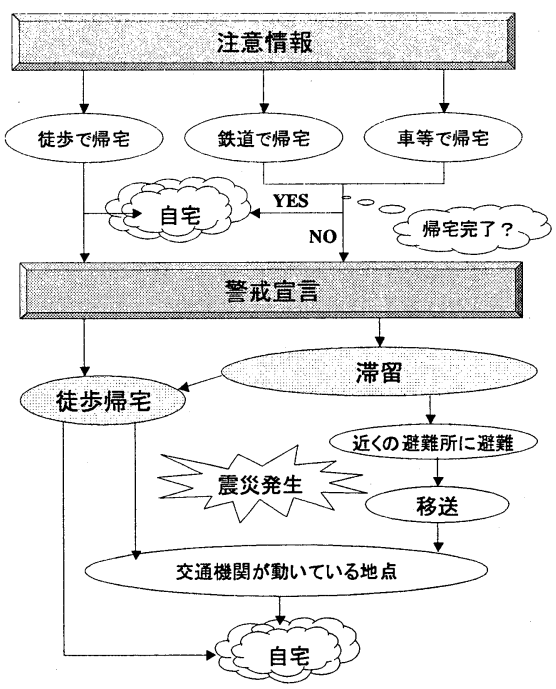

図ー2 警戒宣言による帰宅困難者の動向

で帰宅を促すとする企業・学校が多く存在するため, 地 震発生後の帰宅困難者は名古屋市で約 $50 \%$, 全県で 4 $0 \%$ 弱に減少すると予想されている.

注意情報を認知した後, およひ警戒宣言が発令された 後の帰宅希望者がとりうる行動パターンは, おおよそ図 -2のように示すことができる.

\section{（2）警戒宣言が州宅困難者に与える影響}

東海地震はわが国で唯一，予知の可能性があるといわ れているが，警戒宣言の有無により帰宅困難者の状況が 大きく異なると予想されている.

表ー4に情報レベルと各主体の対応を示すが，注意情 報が震災前に発信されると，警戒宣言前までに移動（帰 宅行動）を済ませておく必要が生じる，しかしながら， 注意情報の発令から警戒宣言までの期間が予期できない ことの不安から, 帰宅行動者が一時的にターミナル駅に 殺到する可能性が高い.

このように，震災前の段階ですでに帰宅困難者が発生 するという事態への対応が，名古屋市等の行政機関や交 通事業者にとって大きな課題となる.

名古屋市では帰宅困難者対策として「滞留者等支援対 策のガイドライン」 ${ }^{8)}$ を定めている.この中では滞留者 等支援刘策と情報提供対策，自助対策が核とされている.

\section{表一4＼cjkstart東海地震(二関する情報レベルと対策5)}

\begin{tabular}{|c|c|}
\hline レベル & 行動および対策 \\
\hline 注意情報 & $\begin{array}{l}\text { ・ 多くの学校・企業で淮備行動を開始 } \\
\text { ・名古屋市が淮備行動を開始 }\end{array}$ \\
\hline 警戒宣言 & $\begin{array}{l}\text { - 公共交通機関がストップ } \\
\text { - 交通规制の実施 } \\
\text { - 地震防災芯急対策の実施 }\end{array}$ \\
\hline
\end{tabular}


特に問題点と考えられるのは，図一 2 に示す警戒宣言 の発令により鉄道が運行不能となることによって発生す る滞留者と徒歩帰宅者の取り扱いである.

a) ターミナル駅の滞留者への影響

名古屋駅では注意情報が発令された後, 最大で10万 人以上ともいわれる帰宅希望者が殺到するが，これらを 全て円滑に帰宅させることは困難であり，警戒宣言発令 後も少なからぬ滞留者の存在が想定される, 帰宅したい のにできない焦りや苛立ちとともに，情報と保護を求め て殺到するため, 対応如何によっては大混乱が生じる可 能性が高い.

b）徒步州宅行動時の混乱

自宅へ向かって歩き出した徒歩州宅者は，帰宅経路を 明確に把握していないケースも多く，正確な情報を得る ための手段も少ない．また，自宅が遠方であるために帰 宅をあきらめたり，帰宅行動開始後の飲食料の確保やト イレ使用等が満たされないなど，徒步帰宅を行う上での 障害は非常に多い。さらに夜間に震災が発生する場合は， 停電による暗闇での行動になると想定され，徒歩による 帰宅はより困難になる。

（3）帰宅困難者(徒歩帰宅者)への支援対策の課題 前節と同様に，支援対策の核である滞留者と徒歩帰宅 者への支援対策の課題について検討を行う.

a) 鉄道駅等の滞留者への対策と課題 2003年に修正された中央防㷋会議の地震防災基本計 画9)では，帰宅困難者の取り扱いについて，「市町村以 外の計画主体は，規制の結果生じる帰宅困難者に対する 具体的な避難誘導，保護ならびに食料等の斡旋の措置を 明示すること」としている，これを受けて，具体的に交 通事業主体と協定を締結している自治体が存在する中, 名古屋市はいまだに未整備である．あらかじめ帰宅困難 者を受け入れる避難所を駅周辺にいくつか指定しておき， 円滑な避難誘導が可能なように，交通事業主体との連携 体制ならびにその責任所在を明示しておく必要がある. さらに，食料等の斡旋については問題が多い. 名古屋市 は震災発生の前段階には備蓄物資を提供しないことにし ているため ${ }^{5)}$ ，避難所にいる帰宅困難者にのみ交通事業 主体から飲食料が提供される状況になってしまう. 加え て, 誰が䚻宅困難者であるのかの判断も困難である。

b) 徒步帰宅行動者への対策と課題

徒步帰宅者が安全に帰宅するには，飲食料，トイレ， 休息場所，帰宅支援情報などが必要であるが，現状では それらの支援設備やサービスが州宅の沿道上に十分用意 されていない：これらを新たに整備することは困難であ るため，既存の施設を利用することを考えれば，ガソリ ンスタンドやコンビニにこの役割を課すことができる. コンビニは偏在があるものの絶対数が多く, 名古屋市内

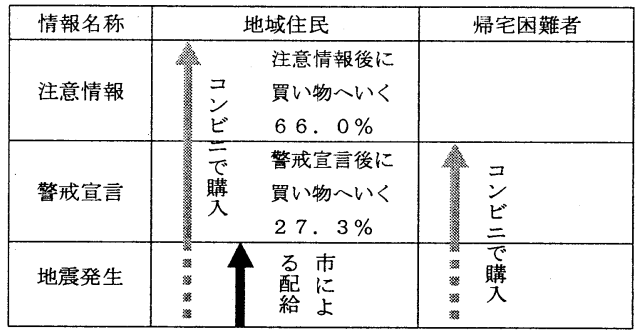

図一３飲食料の確保方法

に広く分布している. コンビニを運営する本来の業務に 加え, 名古屋市との連携体制を確立することによってリ アルタイムでの情報発信が可能になれば，注意情報が発 令された以降に提供される情報は, 徒歩帰宅者にとって 大変有益である. ただし図一 3 に示すように，注意情報 発令後に必要物資を買出しにいく市民が多いと予想され， この段階でコンビニが商品不足となる事態が十分に想定 される.また, 警戒宣言発令以前は交通管理者が交通規 制を実施しないため，大規模な交通啮滞の発生が考えら れ，納品車がコンビ二各店舗にスムーズに到着できなく なる可能性も大である. そこで, 道路交通管理者がコン ビニの納品車を事前に緊急指定車両に認定しておき，円 滑な物資輸送を可能にすることが必要とされる.

発災直後から救援物資が定期的に届けられるようにな るまでの数日間，「コンビニに行けば各種の情報が提供 され，飲料水等の緊急物資が手に入る」ことが州宅困難 者および被災者に与える物理的，精神的影響は極めて大 きいと思われる.

\section{6. 帰宅困難者の保護に関する提言}

滞留地への帰宅困難者の滞在が数日にわたる場合, 飲 食料の確保が重要となってくる. 現状では, 行政や交通 事業者加帰宅困難者への具体的な物資提供施策は未策 定であり，自助が基本となっている.このような状況下 で重要な役割を果たすのがコンビニと考えられる.

5章で述べたように，東海地震注意情報の発令以降， 地域住民が備蓄物資を確保するために近隣のコンビニ等 に押し寄せることが予想され，滞留者や帰宅困難者等が 飲食料を調達できなくなる可能性が大きい，また，一般 の避難所に地域住民と帰宅困難者が混在する場合には, 両者の識別は不可能と考えられる.このため, 行政や交 通事業主体が連携して滞留者队帰宅困難者に対する保護 ならびに食料等の斡旋の措置を行う場合, 地域住民との 混乱を避けるためにはそれぞれに対して適切な「物資を 確保する場所」，換言すると帰宅困難者専用の避難場所 と物資の供給手段が必要になると考えられる. 本章では, 注意情報の発令以降におけるコンビニの機能について, 帰宅困難者への救援物資供給のあり方を主たる課題とし， 地域住民支援との関わりも含めて検討する. 
（1）飲食料の提供方法

東海地震の注意情報発令以降における物資調垟の混乱 を軽減し，帰宅困難者・地域住民一円滑な物資提供を行 うため，注意情報発令が出された以降のコンビニの営業 形態として次の 2 案を提案する.

\section{<通常営業型コンビニ $>$}

「通常営業型」を，(1)各店舗にて営業すること，(2)物 資の提供は有料とすること，(3)商品は消費者の需要に応 えるものとすること，(4)物資が充実し，欠品は極力ない ものとすること，と定義した.

この「通常営業型」の利点は，配送時に交通規制に関 して交通管理者の了解を要するものの，平時とほぼ同様 の体制で営業が行えることにある．しかし一方で，地域 住民・帰宅困難者ともに自己努力によって物資を購入し なくてはならない欠点がある.

\section{く物資配給型コンビニ>}

「物資配給型」を，(1注意情報〜警戒宣言までは「通 常営業型」と同様の体制をとること，(2)警戒宣言以降は 名古屋市の指示に従い，配送センターから直接帰宅困難 者を収容している避難所一物資を配給すること，(3)帚宅 困難者への物資配給により生じた経費はあとで行政が負 担すること，と定義した。

この「物資配給型」の最大の利点は, 不案内な土地で も帰宅困難者が自ら動き回ることなく物資を確保できる ことにある. しかし，行政・交通事業者にとっては帰宅 困難者を誘導する人員と配給に要する経費が必要となり, 大きな負担となる，またコンビニにとっても，配送先が 平時と異なるため, ルートを確認しておく等の特別な措 置が必要となる．さらに，「物資配給型」は滞留する帰 宅困難者一直接领食料を供給するタイプとして地域住民 への配給を考えていないため, 帰宅困難者を優先的に収 容する「州宅支援型避難場所」が必要となる.

（2）飲食料提供を考慮した避難所の選定

本節では，帰宅困難者（滞留者）を保護する場所とし て, (1)広域避難場所, (2)一般避難所としての市立小中学 校, (3)帚宅支援型提供避難場所の 3 ケースを選定し, 帰 宅困難者を保護する避難所に適応した飲食料の提供方法 を考慮する必要がある. ここではその事例として，名古 屋駅周辺地区における帰宅困難者一の対応について検証 を行った. 名古屋市の検討によれば，平日の14時に注意 情報が発令され，警戒宣言発令が16時と17時とされる場 合，名古屋駅においてはそれぞれ約2万人，約1万人の帰 宅困難者の発生が予測されている ${ }^{8)}$.

\section{<広域避䧼場所に避蜼する場合 $>$}

名古屋駅で発生する全ての帰宅困難者を同駅から $2 \mathrm{~km}$ と一番近い広域避難所である「白川公園」に誘導するこ とを考える. 白川公園の勢力範囲は図一 4 に示すとおり

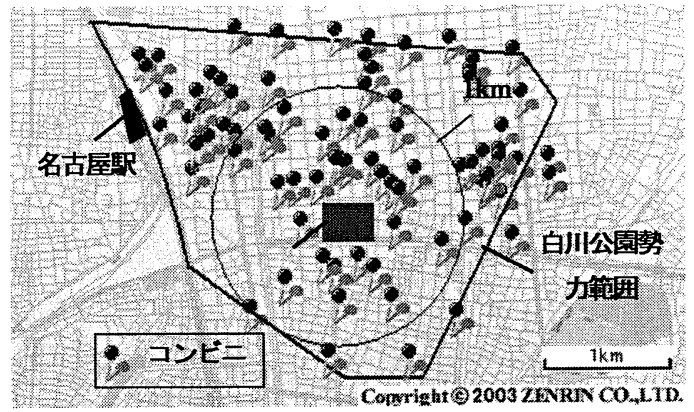

図一４白川公園勢力範囲とコンビ二の配置

であり，名古屋市の資料よりこのエリアでは約 4000 人の 地域住民が広域辟難所への避難を希望する. 白川公園の 収容人数が約 5 万人であることから，地域住民および州 宅困難者 (2.4万人) は全員収容可能であると考えられる。 次に帰宅困難者の飲食料確保であるが，中小企業庁発行 の「コンビニエンスストア・マニュアル」が定める徒歩 消費者が許容するコンビニまでの移動距離は $1 \mathrm{~km}$ 以内で あることから，図一 4 に示すような白川公園から $1 \mathrm{~km}$ 圈 内にある33カ所のコンビニへ帰宅困難者が自助努力によ り物資を購入に行くことを考える. 名古屋市の凟料より, $1 \mathrm{~km}$ 圈内て警戒宣言後に物資を購入に行く地域住民は約 6000 人と推定できることから，地域住民と帰宅困難者を 合わせた約 2.6 万人分の飲食料を 33 所のコンビニが賄 うことになるが，平時における1日当たり来客数は約 5 万人(コンビニの平均来客数 1500 人日より)であること から，商品を飲食料に絞り，配送回数を増加させれば不 可能な数字ではない.

\section{＜市立小中学校に避難する場合＞}

収容人数が少ない市立小中学校に帰宅困難者を避難さ せる唯一のメリットは, 滞留地からの移動距離が短いこ とにある. しかしながら，名古屋駅から $2 \mathrm{~km}$ 圈内にある 市立小中学校のうち, 白川公園より移動距離が短い学校 の收容人数は合計してもわずか約 7500 人であり，2万の 帰宅困難者をすべて収容することは不可能である.

〈名古屋市が応援協定を結んだ民間施設に避難した場合〉

名古屋市が応援協定を締結した民閒施設（以下，民間 施設）の収容人数は1万人であるため，帰宅困難者を全 員収容することは不可能である.このため残りの 1 万人 を白川公園に誘導することが最善の方法と思われる.こ こでは民間施設と白川公園に帰宅困難者を分離して収容 する場合を考える. 帰宅困難者が民間施設から図一 5 に 示寸勢力圈 ( $1 \mathrm{~km}$ 補正圈内) にあるコンビニへ自助努力 により物資を購入に行くことを考える. この圈内にはコ ンビニが14ヶ所存在しており，警戒宣言後に物資購入に 行く地域住民は約 4000 人と推定できる.この結果から， 地域住民と帰宅困難者を合わせた約 1.4 万人分の飲食料 を 1 日あたり来客数約 2 万人の 14 ケ所のコンビニが賄う 


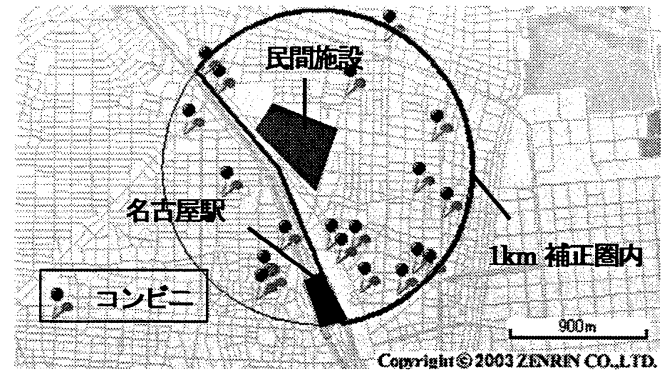

図一 $51 \mathrm{~km}$ 補正圏内とコンビニの配置

ことになることから，「通常営業型」は機能するといえる. 理想的には，地域住民と帰宅困難者を分離でき，帰宅困 難者全員を帰宅支援型避難所へ収容する「物資配給型」 の活用が望まれるが，現状での指定は 1 箇所のみである ことから，「物資配給型をを活用できるのは帰宅困難者数 が1万人を切る場合のみである.

このことから，帰宅支援型避難所に帰宅困難者全員を 収容させるためには，帰宅支援型避難所をさらに確保す べく，名古屋市と民間業者が協定を結ぶ必要がある。

\section{7. おわりに}

本研究では，帰宅困難者への支援のあり方について提 言してきたが，コンビニを徒涉帚宅行動者に対して有効 に活用しようとする試みについては，非常時とはいえ特 定の民間業者の営業活動を行政側が積極的に協力するこ とに関する合意形成の検討が必要となる．コンビニの多 機能・高度情報化の進展は, 街の物資供給点としてだけ ではなく，情報ステーションとしての役割を担う社会シ ステムの一部となってきている. 帰宅困難者保護に関し て提案した「物資配給型コンビニ」や名古屋市の試みで ある「帰宅支援型避難所」 ${ }^{5)}$ にみられるように，自治体 の防災計画における民間企業の位置づけに関してさらに

議論を深める必要がある. 今後は，帰宅困難者数が非常 に多くなる場合, 緊急物資輸送を担う道路ネットワーク 状況，広域かつ甚大な被害が生ずる場合のコンビニの流 通機能に関する諸条件下で，行政側の想定外の事態が発 生した場合を含めたさまざまなシナリオを設定し，物資 提供方法を検証する必要がある.

埽宅困難者の支援施策である居住地までの移送のあり 方やコンビニネットワークを有効活用する緊急時輸送の あり方も今後の研究課題として検討を進める予定である.

\section{参考文献}

1）東京都：東京における直下地震の被害想定に関する調 查報告書, 1997.8

2）中央防災会議：南関東地域直下の地震対策に関する大 綱，1998.6改訂

3）東京都：震災時における中間都民対策檢討委員会報告, 1999. 3

4）永田尚人ほか：帰宅困難者対策としての地下空間のあ り方の一提案，地下空間シンポジウム論文・報告集， 第10巻，pp. 59-68, 2005.1.

5）名古屋市：名古屋市防災会議「名古屋市地域防災計画 (地震対策編) 」, 2001

6）山本幸司ほか：コンビニ利用を前提とした震災直後の 救援物資提供システム，第14回日本都市計画学会中部 支部研究発表会論文・報告集, pp. 17-20，2003.10.

7）愛知県 : 愛知県防災会議「愛知県東海地震 - 東南海地 震等被害予測調査報告書」，2003

8）名古屋市：「名古屋駅地区滞留者等対策検討委員会提 言書」, 2003.3

9） 内閣府：中央防㷋会議「東海地震の地震防琰対策強化 地域に係る地震防災基本計画」，2003.7

\section{大規模地震時における帰宅困難者支援に関する一考察*}

永田 尚人 ${ }^{* *}$ 西村 典子 $^{* * *} \cdot$ 山本 幸司 ${ }^{* * *}$ 大都市部における大規模地震発災直後において，主要な輸送機関である鉄道の運行停止等により多くの帰宅 困難者の発生が予測されている．帰宅困難者は徒歩により帰宅を行うものと考えられるが，帰宅経路の安全状 態や被害状況に関する情報とともに，帰宅経路における食料や飲料水の確保が大きな課題となる．本研究では， 東海地震に対する警戒宣言発令後における交通輸送機関の麻晫により発生する帰宅困難者の問題点を明らかに した上で，飲食料等確保の観点からコンビニエンスストア活用のあり方について検討を行うことを目的とする.

\section{Supporting Measures for the Difficult to Return Home at the Earthquake Disaster *}

By Hisato NAGATA $^{* *} \cdot$ Noriko NISHIMURA $^{* * *} \cdot$ Koshi YAMAMOTO $^{* * * *}$

At early stage after the large-scale earthquake disaster in the metropolitan area, it is very important for the difficult to recognize the damage situation on the evacuation route, securing food and water during returning home, and so on. In this paper, the problem of the difficult to return home at the Tokai Earthquake has been made clear which outbreaks with the interruption of public transportation. Furthermore, this paper shows the convenience store has been utilized in order to supply water and food just from the aspect of supporting measures for the difficult to return home. 